\title{
Household Livelihood Strategies Among the Keiyo in Kenya
}

\author{
John Koskey Chang'ach \\ Moi University, Eldoret, Kenya
}

\begin{abstract}
The paper demonstrates that people in all three ecological zones of Keiyo try to diversify their economic opportunities. Moreover, the paper suggests that Keiyo diversify both in order to reduce risk and uncertainty and in hopes of succeeding financially and getting ahead. On the other hand, it has shown that the interaction of ecological factors has limited the economic opportunities that are available to most people in the valley, and to a lesser degree, on the escarpment. The highlands ecological zone provides the greatest opportunities for achieving economic security and success. Usually through a combination of on-farm and off-farm activities, households are able to live more comfortably there than in the other two areas. Ironically, however, it is also in the highlands that diversification of activities becomes least essential for economic survival and prosperity. Because of the much more favourable opportunity structure there, households in the highlands do not feel as compelled to diversify their economic activities as do people who lived in the valley or on the escarpment. Nonetheless, this paper demonstrates that diversification is still the most common strategy pursued in all three ecological areas.
\end{abstract}

Keywords: Keiyo, Kenya, household, ecological zone, highland, escarpment, valley floor, diversification, livestock

\section{Introduction}

The three ecological zones in Keiyo are the highlands, escarpment, and Kerio Valley floor. The strategies that individuals and households use in the pursuit of their livelihoods and the activities in which they are engaged are affected by economic differentiation. In this paper, it is suggested that although diversification of economic activities is a strategy shared by people of all three ecological zones, there are vast differences between these three areas in the ability of people to diversify their enterprises. The paper seeks to demonstrate that while most people seek to diversify, their ability to do so is limited, to varying degrees, by the opportunity structure of their area.

\section{Research Instruments}

In the selection of the instruments to be used in the study, the researcher ensured that the objectives of the study were clear and well suited to the instrument chosen. The instruments used for data collection were through in-depth interviews and focused group discussion. These methods provided data that were not possible to obtain using questionnaires. Through these methods, the researcher clarified questions that were not clear.

Purposive sampling is a non-probability technique which allows the researcher to use cases that provide required information with respect to objectives of the study. In this regard, the sampled respondents provided the requisite information through in-depth interviews and focused group discussion.

John Koskey Chang'ach, Ph.D., professor, Department of Educational Foundations, School of Education, Moi University. 


\section{Who Are the Keiyo?}

The Keiyo are part of the larger grouping of eight culturally and linguistically related ethnic groups known as the Kalenjin, a heading which includes the Kipsigis, Nandi, Tugen, Marakwet, Pokot, Sabaot, and Terik (Chang'ach, 2011a). These groups were earlier known collectively as Nandi-speaking peoples or alternatively, as the southern Nilo-Hamites (Kipkorir, 1973). The more recent name Kalenjin, which translates as "I tell you," is a relatively new historical phenomenon dating to the time around World War II, and stemming from a desire to draw political strength from the larger numbers such an association would bring (Huntingford, 1963).

\section{Crop Production}

According to Sessional Paper No.1 of 1986, Kenya's food security remains a major objective of the government. The nation's farmers have to continue to provide the surplus that needs to finance economic development for the rest of the country. Agriculture has to generate household incomes and stimulate the growth of productive off-farm activities in rural areas (Republic of Kenya, 1985). To achieve these goals for agriculture, several strategies have been pursued. Farmers are encouraged to adopt more productive practices, especially the wider use of improved varieties, fertilizer, disease and pest control, pricing policies, and marketing policies and institutions and the extension services can be the main instrument in obtaining much higher yields through known techniques.

Research into new varieties, especially maize and other grains, should be re-organized and accelerated to generate the new, high yielding varieties that are essential to keep pace with consumption (Republic of Kenya, 1985). There are no large farms in the Keiyo and all data available refer to the small farm sector.

In the highlands, Irish potatoes and maize are grown as the main food crops whereas pyrethrum and tea are grown as cash crops. In soy division, groundnuts are grown as food and cash crop. The more productive economic structure of the highlands means a greater degree of economic security is manifested here than the other two zones. Therefore, the households in the highlands are well-off of the three ecological zones.

An overview of Keiyo shows that the percentage of cash crop producers is still low compared with that of food producers. Most of the income generated from both cash and food crops are for improving the living standards of the majority of the people within the area.

Maize is grown throughout the Keiyo and the potential yield is high, up to 45 bags per hectare (Republic of Kenya, 1991a). The crop can also be used as a cash crop, especially where it is grown in large quantities and so it plays a double role of food and a cash crop. The potential yield of beans is 5-8 bags per hectare (Republic of Kenya, 1991a). Consumption is mainly in institutions like schools. Beans are also sold in the local market and outside the area to fetch income to the households.

Finger millet is grown in Kerio Valley and the escarpment. The area's potential is not fully achieved due to scarcity of certified seeds, moisture stress, and damage from birds. Finger millet is predominantly grown as a food crop. The same applies to sorghum production (Republic of Kenya, 1991a). Irish potatoes are mainly grown in Southern Keiyo. The district's potential of 25 tonnes per hectare has not been realized due to the use of poor seeds for planting and poor farm management (Republic of Kenya, 1991a). It is both a cash crop and a food crop.

The area's potential for wheat production is 30 bags per hectare, but achievement is only 25 bags per hectare (Republic of Kenya, 1991a). Factors like lack of mechanization, diseases, and pest problems prevent 
the potential from being achieved. Wheat is mainly grown as a cash crop, although sometimes used as a food crop. Tea is mainly grown in Southern Keiyo under the Nyayo Tea Zone as a cash crop. The yield is poor and there are no organized tea picking centres. The harvested tea is sent to factories in Nandi Hills for processing. The distance discouraged farmers from growing more tea. Currently, a tea factory is being built at Flax, Kaptagat. Coffee is grown as a cash crop. The potential for the crop is 7 tonnes per hectare but achievement is 3 tonnes per hectare (Republic of Kenya, 1991a). Pyrethrum potential yield is 0.8 tonnes per hectare but 0.6 tonnes per hectare is produced (Republic of Kenya, 1991a). Low yields are due to poor farm management and labour constraints.

The evidence gathered shows that income from crop production contributes greatly towards the general incomes of the household within the area. Yet, it is also clear that maize generates higher incomes than other crops. Maize is grown in the three ecological zones. The income from maize production alone contributes $74 \%$ of the output.

The net area cropped is higher in the highlands compared to the escarpment and the valley. In all the three areas, maize and beans dominate the cropping pattern, although the level of intercropping differs from area to area. The maize varieties cultivated at the escarpment and the valley are adapted to more harsh climatic conditions, and these varieties need 4-5 months to mature. The maize varieties on the top of the escarpment take much longer due to cold and moist conditions. Less than $20 \%$ of the maize and about half of the beans are sold, while the rest is consumed within the household (Chebet \& Dietz, 2000). The traditional crops of the valley, such as finger millet and sorghum, are still cultivated for home consumption and for the brewing of local beer.

The cultivation of commercial vegetables has become important for most of the farmers in the highlands and less on the escarpment. In the highlands, most farmers cultivate vegetables, pyrethrum, and Irish potatoes for commercial purposes. The farmers in the highlands apply modern farming methods.

Generally, the lowland has more crops being consumed at the household level than in the highlands. In the highlands, it is estimated that households consume about $40 \%$ of their total production. The total value of the home consumed crop is higher in the highlands than on escarpment or valley, both monetary terms and in kind. The food value available for household consumption shows that households in the highlands have ample provision of calories and proteins. However, also in the lowlands, the level of food sufficiency is surprisingly high for most households.

Most households spend money on farm operations. In the highlands, almost all farmers spend money on casual labour, seeds, fertilizers, agricultural implements, and tractor hire services. On the escarpment and in the valley, most farmers spend less on fertilizers and casual labour. Hardly any money is spent on tractor hire services due to the difficult terrain (Chang'ach, 2011b). In the three ecological zones, farmers dip or spray their cattle against tick-borne diseases, while they spend unknown but considerable amounts of money on veterinary services.

\section{Livestock Keeping}

The main types of livestock reared in Keiyo include beef cattle, dairy cattle, hair sheep and wool sheep, small East African goats, poultry, rabbits, pigs, donkeys, and honey bees. The introduction of exotic breeds for upgrading purposes has improved the quality of livestock products and the general living standards of the people (Republic of Kenya, 1991b). 
Farmers are interested in dairy farming as opposed to pastoralism which was the trend in the past. Rearing of wool sheep is also common as compared to local sheep. The only problem that farmers faced is that there are no wool co-operative societies within the area. New trends in livestock production have been introduced, such as Dorper sheep from Laikipia, and Boer goats from Nyeri as well as Turkeys and Ducks. Modern beekeeping using Kenya Top Bar Hive (KTBH) improved (Republic of Kenya, 1991b).

Sheep production in the area especially wool production is not popular due to lack of market. Majority of the wool sheep, for example, Merino, Romney, Mash, and Corriedale, are concentrated within the highlands while the hair sheep, such as Red Maasai, are concentrated in the valley and on the escarpment.

Major constraints are diseases like contagious Pleuro-Pneumonia and inbreeding, which reduce the body size and growth rate of the animals. The biggest challenge is lack of appropriate wool breeds and their sources. Nevertheless, there are serious awareness campaigns on proper sheep husbandry for wool production (Republic of Kenya, 1991b).

The goats kept are mainly for meat and in small numbers milk production. Meat goats are mainly kept on the escarpment and in the Kerio Valley, and the small East African goats are predominantly kept. The dairy goats have not gained popularity as an alternative source of milk to the dairy cow (Republic of Kenya, 1991b). This is due to the community socio-cultural beliefs. The Ministry of Livestock promoted dairy goats within the valley especially the German Alpine of which the response from the community is quite positive.

The dairy goat project is viable enterprise especially for the smallholder farmers along the valley. The majority of poultry kept are the local chicken under free range management system with minimum feed supplement and moderate housing structures. Marketing is a major constraint in the commercial poultry sector whereby farmers fail to get good returns to sustain the enterprise and the households due to long distance to competitive markets. Eldoret town and hotels in Iten town are the main market outlets for poultry and products from the district (Republic of Kenya, 1991b). The pig keeping is not popular in the district due to low management skills and market constraints. The few animals kept are by the institutions in the area. The pigs kept are crossbreed Landrace and Large White.

There is no group in the area that is seriously involved in value addition of honey except the Kerio Valley Development Authority (KVDA), which served a limited area in the valley and this was the reason why most of the bee-keepers sold their honey in crude or semi-crude form (Republic of Kenya, 1991b). Honey processing was done by Rokocho honey refinery centre owned by the KVDA. The bee-keepers are also embracing modern methods of beekeeping, such as use of the KTBH.

Cattle production activities in Keiyo are in accordance with the three distinct topographical features, namely, the highlands, the escarpment, and the Kerio Valley. This was due to differences in altitude and rainfall amounts. The main types of cattle are dairy, crosses, and zebu. The dairy cattle production has increased because farmers have adopted new modern methods of farming.

Most of the animals are sold to other neighbouring counties especially Uasin Gishu. All the hides and skins are sold to Uasin Gishu tanneries. The milk is sold to processing plants in Eldoret and other areas. A small percentage of honey is consumed locally. The refinery at Rokocho owned by KVDA processes the rest.

Virtually, all households own livestock. In terms of the livestock unit, the highland area does not differ much from the valley area. However, on the escarpment, it is only half of the levels of the highland or the valley. In the highlands, grade cattle and crossbreeds dominate the livestock pattern, followed by zebu cattle, goats, sheep, and chicken. Milk production is considerable and a quarter of that milk is sold, mainly to a milk 
co-operative society, which is owned by the farmers. On the escarpment and in the valley, grade cattle or crossbreeds are few. On the escarpment, there are higher numbers of zebu cattle, goats, and sheep than in the valley.

Within the commercial and subsistence livestock production, milk production dominates in all the three areas. The milk income level in the valley is considerably lower than that of the escarpment and the highlands. In the highlands, half of the total farm income comes from livestock and the milk. A minority of households in the lowlands sell honey. Most households use it for home consumption, for medicinal purposes to make a local honey brew, and as a delicacy.

Non-farm activities are very important in the three zones. For the escarpment and especially for the valley, the presence of Flourspar Company makes a considerable difference compared to other parts of the Kerio Valley, where the non-farm income opportunities are much more invisible. Also, on the escarpment, a number of people are much more invisible. Moreover, a number of people are employed by the rural access roads programme. For people who want casual labour, opportunities exist, for example, fencing, weeding, harvesting, and constructing a hut, which are paid per day's work (or predetermined sum of money). In monetary terms, these casual jobs and local contracts are readily available opportunities. Others are employed in the civil service which is an important income-generating activity besides casual and contractual jobs (Republic of Kenya, 1991b).

In the three zones, some people own transportation business (public service vehicles). Others are in self-employment, such as shops and selling charcoals. The information used in the discussion of this paper has suggested that the highland area is better than the valley and the escarpment; the prevailing conditions indicate that both the valley and the highlands have comparable economic potentials in income terms if the people can use the opportunity.

\section{Economic Activities}

Since majority of Kenyans are poor, there is a need to achieve economic growth through the use of their productivity. Failure to tap the poor's potential contribution to employment creation and growth will severely handicap the national economic effort. When low income groups are so numerous, it is no longer desirable or even feasible, to exclude their productivity potential, create surpluses in highly productive sectors, and then use those surpluses to alleviate their poverty by means of welfare and relief payments (Republic of Kenya, 1999). What is required is a broad-based economic growth which starts from the need to protect and enhance the assets and income streams of those who are poor. The assets they work with include their human capital and labour skills and the social capital found within social networks and community institutions. It is these personal skills and social networks which provide employment, safety nets in times of distress, and routes to savings and remittances used for investment purposes when the formal employment sectors do not help. There is a need, therefore, to find ways of assisting the households to increase the range and quality of their productive opportunities and livelihood choices.

The creation of productive employment opportunities is one of the most serious challenges facing households in Keiyo. A central component of the larger efforts towards economic growth, poverty reduction, and increased employment is the strategy for the balanced development of rural areas (Republic of Kenya, 1999). Improved productivity and output in agriculture which is essential for overall economic growth is closely linked to services and inputs provided from accessible urban areas. 
The ability of people to meet their expectations in life is also a concern of this study. The equal resource distribution across ecological zones also affects people's attitudes about what they feel they can and cannot achieve in life. The persons who lived in the area with most favourable economic opportunity structure are those who are able to meet more of their economic expectations than persons who are less favourably endowed with resources. Diversification of economic activities is a common livelihood strategy of small farmers and rural households, not only in the developing world, but also in parts of developed nations (Halperin, 1992). Because people in these settings perceive a relatively high degree of risk and uncertainty in their environment, they engage in a variety of activities in order to reduce these feelings of uneasiness (Ortiz, 1973). The rule of thumb is: trying to avoid placing all your eggs in one basket, or less metaphorically, diversifying to reduce risk and uncertainty. Moreover, these same activities can also enable some households to earn substantial amounts of money and to "get ahead," to varying degrees (Chang'ach, 2011b).

In an effort to assess what kinds of things people do to reduce risk and uncertainty, informants were asked the following question: "What kinds of things do you do to reduce uncertainty in your livelihood?" Based on the patterns that emerged in the responses, activities were divided into four categories:

(a) Small-scale economic activities (casual labour, charcoal burning, making and selling beer, craftwork such as making calabashes or ropes, and financial remuneration from relatives);

(b) Salaried employment (with the government or a private company) or wage labour (working locally in a business, such as a butchery or bar);

(c) business endeavours/entrepreneurial activities (ownership of a bar, duka (small retail shop), or a matatu (public transportation vehicle);

(d) Both salaried employment/wage labour and business endeavour/entrepreneurial activity.

All these activities are normally carried out in conjunction with, rather than as alternatives to, agriculture.

It is suggested that category four (combining salaried employment with a business enterprise) is the most desirable option for people in terms of both reducing feelings of risk and uncertainty and also due to the potential for getting ahead. Categories two and three are the next best options respectively. While category one (small-scale activities) is the least desirable, since it is the least diversified.

Nonetheless, there are vast differences in economic ability separating category one from category four; going from one end of these categories to the other, the likelihood of the average household being able to engage in these activities diminished greatly. Nearly every able bodied adult, regardless of age and gender, is able to engage in casual labour; such as working for the neighbours during critical periods in the agriculture cycle, such as land preparation, planting, weeding, or harvest. In terms of more gender specific small-scale activities, for men, there is the burning of charcoal, while for women, the making and selling of beer can bring in a cash income. In the three ecological zones, craftwork is a relatively insignificant source of income; even for those few who engage in these activities, they are still only performed on a part-time basis.

Some older persons are no longer physically able to engage in such casual labour as the burning of charcoal or the brewing and selling of beer. Moreover, their ability to work on their own plots has also diminished with advanced age. These people tend to rely on their relatives for food, clothing, or money. This source of support is especially important for the older people with children or grandchildren who may be employed in urban centers like Eldoret, Iten, and other major towns. Indeed, kinship continued to act as a support system in contemporary Africa (Chang'ach, 2011a). 
The possibility of a person securing salaried employment with the government or with major private firms in Eldoret, depends on several factors. The most important is educational qualifications and personal social networks (Chang'ach, 2011a). Local jobs also, at least ostensibly, depend on both educational qualifications and personal connections. In and around the Fluorspar Mining Company, the possibility of securing employment is high.

Business endeavours and entrepreneurial activities, such as ownership of a bar or small retail shop $(d u k a)$, provide one of the best means of insuring an individual and his/her family against uncertainty stemming from dependence on the vagaries of climate (rainfall and temperature) or labour shortages in the production of crops or animals.

Nevertheless, a few people are ever able to do so, because the ability to invest in a business is heavily dependent on relatively large amounts of capital (Chang'ach, 2011a). Thus, entrepreneurial activities are restricted to a very small number of individuals and households. Moreover, this is the most certain path to affluence, but it is also a highly unlikely one for the vast majority of people because of lack of capital (Chang'ach, 2011a).

\section{Agricultural Activities}

Agriculture is by far the largest source of gainful employment in Kenya and will continue to be so until into the next century (Republic of Kenya, 1999). A dynamic agricultural sector is central to the economic development of the country and requires a long-term strategy for employment creation and transformation of the economy (Republic of Kenya, 1991b). Agricultural performance is crucial for the households because it provides vital ingredients for economic transformation, such as demand, foreign exchange, raw materials, food, and labour. These are the five traditional economic roles of agriculture in the process of development (Republic of Kenya, 1991b).

As part of their diversified livelihood strategies, nearly all households in Keiyo are engaged in some crop production. Farming is the basis of life for most people, although the degree to which they depended upon agriculture varied across and within the three ecological zones (Chang'ach, 2011a). Furthermore, the types of crops that can be grown, the amounts that can be produced, and the use to which they are put varies in the three ecological zones (Chang'ach, 2011b). In this section, similarities and differences in the ways that agricultural activities fitted into the livelihood strategies of people in the three ecological zones are considered. Although there are staples, such as maize, which is grown across the three ecological zones, the numbers and types of crops that could be grown in the highlands, escarpment, and valley differed.

The average number of crops grown by households is greatest in the highlands, lowest in the valley, and intermediate on the escarpment (Chang'ach, 2011a). In the lower elevations of Keiyo, the number of different crops that can be successfully grown declines, due mainly to inadequate rainfall. The valley can be very productive with irrigation (Chang'ach, 2011b).

There are differences between these areas not only in the number of crops that can be grown, but also in the types of crops that can be grown. Today, maize tends to be the staple crop of people in all three ecological zones (Chang'ach, 2011a). Just as in much of Africa, maize has displaced the traditional cereals, such as finger millet and sorghum, for several reasons (Acland, 1986). One advantage of maize is that it is less susceptible to damage from crop pests, such as weaverbirds, than is millet and sorghum (Chang'ach, 2011b). In the days prior to universal primary education, children (along with older adults) could spend much of their time on elevated platforms in the fields to scare away birds and wild animals (Massam, 1968). Another reason for the 
popularity of maize is that it requires less labour during weeding, harvest, and processing than those other grains; it is a labour-saving crop compared to the indigenous grains (Schneider, 1981). People continue to grow sorghum or millet especially for use in brewing beer. However, older informants routinely stated that they grow much less of these grains than they did in the past. The reasons they give for this change in the amount of millet or sorghum planted centre on the greater amount of work they require and its tedious nature. Maize has acquired a higher monetary value than millet and sorghum and the Keiyo farmer responded to widening market opportunities. Moreover, maize serves the dual purpose of being a commercial crop as well as being a subsistence crop (Chang'ach, 2011b). In other words, a farmer does not plant maize with the sole aim of trading it off, but consuming it at home. Finally, and not least of all, gastronomically speaking, people have acquired a definite taste preference for posho (maize meal) over millet and sorghum. Though maize is considered as a food crop, it is a cash crop as well for it is an important money earner for both small-scale and large-scale farmers.

Although maize is the number one food crop in all three ecological zones, including the valley, it is not necessarily the one that is best suited to the ecological conditions prevailing in these areas (Kipkorir \& Ssenyonga 1985). Indigenous grains, such as millet and sorghum, are more drought-resistant and can be safer alternative yet most people today plant maize as their primary food crop. Likewise, the number two food crop for all three ecological zones is beans, despite the fact that crops, like cowpeas, can be better suited to the drier conditions of the valley.

In the highlands, apart from the substitution of maize for millet and sorghum, Irish potatoes are widely grown in large quantities where the climate and soils are suitable for the growing of the same. The Irish potatoes are popular in these areas not only because of its commercial value, but also due to the fact that it matures in a shorter period than other available crops. It needs very little labour and the yields are very high. Finally, potatoes like maize serve the dual purpose of being a commercial as well as subsistence crop.

The distribution between "cash" and "food" crops is often an artificial one imposed by the observer (Little, 1987). Many people in Keiyo, like people in other parts of the country, grow crops, such as maize, for sale and consumption. Although some amount may be grown for consumption, this amount can be altered by reality. People often face emergency needs for cash: medical expenses, school fees, and funerals. If an emergency arises around the time for harvest or thereafter, some of the maize that is intended for consumption can end up being sold, often for low prices to local entrepreneurs. Furthermore, and unfortunately for the households involved, they later have to buy this maize back at inflated prices.

For the people of the escarpment and the valley, these crops which are grown for food also tend to be those crops which are grown for sale. Households in the highlands are located in much closer proximity to the daily market in Eldoret than are people on the escarpment and in the valley; this strongly influences the crops that they choose to grow. Kale, cabbages, and tomatoes do well in the better growing climate of the highlands. Moreover, their greater perishability makes growing and transporting them from lower elevations less viable. On the other hand, maize and beans, once dried, can be stored for relatively long periods of time. Finally, it should be noted that the bananas, which are noted as the second most important cash crop on the escarpment, are sold locally and on a very small scale. By and large, bananas bring a small but steady source of income.

\section{Agricultural Inputs}

Crops do not grow by themselves. People have to invest time and money to produce them. For the most part, households in the highlands spend greater sums of money on agricultural inputs than people on the 
escarpment or in the valley (Republic of Kenya, 1997). Accordingly, households in the highlands earn significantly more from the sale of crops than do households in either of the two other ecological zones (Republic of Kenya, 1991c). In order to do so, they invest more money in a greater variety of inputs, such as seeds, fertilizers, pesticides, and herbicides. Agricultural production is more capital intensive in higher elevations than it is in the lower elevations (Republic of Kenya, 1994). The average amount that people spent on agricultural inputs is significantly higher in the highlands than in either the escarpment or valley. Even the average amounts that people spent on inputs are more on the escarpment than in the valley.

However, this finding is partially due to the nature of soils in these three areas; for example, some require more inputs of fertilizer than others. The soil on the Elgeyo escarpment, which is close to the face of the escarpment, does not require the addition of chemical fertilizers or, perhaps only minimal additions. This is because the gradual but inexorable erosion of the escarpment is constantly enriching these soils, making them some of the most productive in the area. On the other hand, much of the soil in the highlands has been intensively used for four to five decades and requires greater additions of fertilizers in order to retain any productivity. Thus, the fact that more chemical fertilizers are used in the highlands is caused by both economic and ecological factors.

\section{Agricultural Labour}

Labour often represents a major constraint on small-scale agriculture in Africa (Schneider, 1981) and, in this respect, Keiyo is not different. Labour bottlenecks occur at critical periods in the agricultural cycle. Like other Africans, the Keiyo have devised social arrangements that help them overcome these restrictions. In the three ecological zones covered by this study, the number of households that needs outside help at some period during the year is high.

Co-operative labour parties are well documented in the literature on African production systems (Karp, 1978). Neighbours co-operate in tasks such as breaking the land, planting, weeding, or harvesting in return for reciprocal assistance at a later date or a beer party. While these kinds of arrangements continue today in Keiyo, some people have taken to performing this labour in return for cash. This practice is known as casual labour, or kibarua (Chang'ach, 2011b). Nearly all these options involve some expenditure of money, and most households are forced to expend cash to secure the extra agricultural labour they need. Although agriculture is still important for subsistence in the valley, it is a less critical part of households' livelihood strategies there than it is in the highlands.

\section{Earnings From Agricultural Activities}

Households in the highlands invest more money (inputs and labour) in crop production than their counterparts in the valley or on the escarpment. However, it is true that people in the highlands also earn more money from crop sales than do households in the valley or on the escarpment. This is because people in the highlands can grow a greater variety of crops than is possible on the escarpment and in the valley. Furthermore, in the lower elevations, those crops which are grown for food tend to be those which are sold for cash, such as maize and beans. In the highlands, on the other hand, although people still sell maize and beans, their major cash crops (kale, cabbages, Irish potatoes, and tomatoes) are different from their staple food crops.

Before concluding this discussion of agricultural activities, it is necessary to consider for a moment the various outlets that people use for selling their crops. Generally, befitting the strategy of diversification, most 
households use a variety of outlets for crop sales rather than relying on a single channel. Furthermore, this generalization holds true across ecological zones. For example, although the National Cereals and Produce Board (NCPB) is the official buyer for maize in Kenya, people from all three ecological zones do not only sell maize through this channel; instead, they tend to market their crops through a combination of sources. This includes local individuals, local shops, local schools, middlemen, and a combination of some of them. Accordingly, all the households in the three ecological zones market their crops utilizing a number of different outlets because this allows households to take advantage of unexpected situations that arise during the course of the year than if they are locked into a rigid predetermined pattern.

\section{Livestock Related Activities}

Livestock is of great importance to people in the three ecological zones of Keiyo. The types of livestock products that people depend upon for subsistence or for sale vary from one ecological zone to another. Small ruminants, sheep, and goats are primary sources of meat. As such, they are both sold and consumed by members of households. The indigenous breeds of cattle that are kept in the valley have lower milk producing potential than those crossbreed cattle that are kept in the highlands (Republic of Kenya, 1991c).

Livestock production is an important sub-sector within the agricultural sector as animals play a major role in the livelihood of households in the area. Emphasis on livestock compared to cropping is on the decline in the highland zone where people prefer growing maize and wheat. In spite of this, households in Kerio Valley keep large herds of zebu cattle, while others are scattered in the highlands. They are kept as a tradition but not for commercial purposes. Occasionally, when the need arises, farmers can sell one or two animals to get cash money.

Milk production is both exotic and indigenous zebu cattle. However, milk from the zebu is so little that most of it is either consumed at home or sold locally. Thus, the dairy industry is largely maintained by grade cattle.

Beekeeping and honey production is a common practice among many traditional beekeepers in the Keiyo. The exploitation of flowering trees and shrubs for honey production is of paramount importance in the Kerio Valley where households depended on smallholder agriculture with local zebu, sheep, goats, and honey as their primary source of income. However, no organized honey production and marketing has taken place in the area. The honey produced is consumed locally either fresh or in preparation of local liquor (Kipketinik). If the potential is fully exploited, then there could be a justification for setting up a refinery in Rokocho in the valley floor.

Not only do the types of livestock products that are being sold vary between ecological zones, so also do the outlets for sale. Overall, households in the valley are more limited in their avenues for sale than are people in the highlands. Other than individuals in the area, the butchers in small trading centres constitute the primary conduit for the sale of animals from the valley and also those animals that are kept on the escarpment.

Just as with crop sales, the amounts of money that can be earned from livestock sales vary greatly across ecological zones. The average amount of money which households are expected to make from the sale of animal and milk is greater in the highlands than either the escarpment or the valley. On average, households in the highlands estimate that they can make over three times more from these sales than households in either the escarpment or valley.

Furthermore, the earnings from livestock and its products are not equal within and across the three ecological zones. However, once again, like the situation with crop production, the greatest income earning 
potential of livestock in the highlands also require more investment of money in form of veterinary care. The crossbreed cattle of the highlands do produce larger quantities of milk, but they are also more susceptible to tick-borne diseases like East Coast Fever; hence, they can only survive if they are regularly sprayed with or dipped in chemical solvents to kill these parasites. Although the Kenya government, through the Ministry of Livestock development, is trying to encourage preventive health care for all animals (both indigenous and exotic/crossbreed), households in the lower elevations of Keiyo are less likely to do so, partly because of the cost. In addition, to the consideration of cost to the users, there is also the element of maintenance to consider. This is not so much of a problem in the highlands, with its relatively well-developed road system, but it is especially problematic in more remote parts of the valley.

Households in each of the three ecological zones are asked to estimate how much they expected to spend on veterinary care for one year. The data demonstrated that on average, people in the highlands spent over three times as much on animal care as do people in the valley or on the escarpment. Once again, a major point is reinforced, that in the highlands, livestock are primarily a source of income, while in the valley, they are important for subsistence purposes.

\section{Wage Labour/Salaried Employment}

A broad definition of employment is an income earning activity, the application of human labour to the task of providing goods and services. Employment may take the form of wage employment that is work done in a firm or household on behalf of an employer for a periodic payment called salary or wage (Republic of Kenya 1997). Alternatively, it may be self-employment, when one works in one's own firm, farm, or business in expectation of some income. This may take the form of actual goods produced and consumed in the household, as in case of subsistence farming or of some monetary gain or profit as in the case of a small roadside kiosk run by the owner.

Employment, in the broad sense of income earning activities, is central to national economic development and household welfare. Labour is the human factor in production. Employment of more and more labour-equipped with appropriate skills and technology and combined with other resources like land and capital is the principal instrument for increasing the production of goods and services and thereby promoting economic growth and development. At the same time, it is through such participation of its members in production and development that a household earns its income and the opportunity to consume, save, and invest. These are the essential determinants of the economic welfare enjoyed by a household. The level of welfare depends not only on the extent of the household's participation in productive work, but also on the quality of that participation, that is, on the level of skills of the workers, the technologies at their disposal, the infrastructural facilities available to them, and the quantity and quality of complementary resources of land and capital (Maxon, 2003).

Unemployment on the other hand occurs when a person of working age, who is able and willing to work, finds none. It follows from the above that this has two implications: 1. The household loses the goods and services which this person, if employed, would be able to produce; and 2. The household concerned is denied the economic and social wellbeing which this person's earnings would enable it to enjoy. Underemployment occurs when the person may be working full time but has poor levels of education, skill, infrastructural facilities, and other complementary resources so that a meager output is produced (Leys, 1975). This phenomenon results in loss of potential output of goods and services to the welfare of the household. 
These and other considerations indicate that creating adequate opportunities for fully productive employment of all members of society who are willing and able to work must be central to the process of economic development. Employment is also the principal means of creating a society in which all individuals and households have rightful share in the benefits accruing from social and economic progress.

Access to employment opportunities tends to be greater in the higher elevations of Keiyo. However, the Fluorspar Mining Company in the valley provides employment opportunities both directly and indirectly to people from the three ecological zones. Otherwise, wage earning positions are extremely scarce anywhere except in the highlands, and even there, they are not plentiful since lack of jobs is a chronic problem of the Kenyan economy today.

Furthermore, getting a job is not simply a matter of accessibility but also educational qualifications. Households in the highlands generally tend to be better educated than households on the escarpment and in the valley; hence, they are usually better qualified for the few jobs that existed. Consequently, the amount of income that households expect to earn from wage labour/salaried employment is greater in the highlands than in the other two ecological zones. Thus, on average, income gained from these sources for households in the highlands is higher than from the escarpment or the valley (Chang'ach, 2011b).

The focus, therefore, should be to protect and enhance the assets and income streams making up rural livelihoods. Searching for poverty-reducing techniques and building and enhancing social capital through group co-operation, support for marketing initiatives for lower income groups, and removal of local and national government regulations which obstruct petty trade, will improve livelihoods and contribute to broad-based economic growth.

\section{Small-Scale and Entrepreneurial Income-Generating Activities}

Entrepreneurship consists of the ability to organize production and the willingness to assume risks. The entrepreneur is the owner of a business; he/she takes decisions on what to produce, how to produce (technology employed), and for whom to produce (markets). If there is a profit after meeting all costs, he/she takes it; if there is a loss, he/she bears it.

One of the most fundamental assertions in this study is that Keiyo people, like people in rural communities elsewhere in the developing world, do many different things in order to survive; they diversify rather than specialize their economic enterprises. Although agriculture is the most important means of making a living for most of the households of these three ecological zones, by no means do these activities exhaust the range of possibilities. Households in all the three ecological zones try to do other things in addition to growing crops and keeping animals; however, their ability to do so varies.

The heading "small-scale income-generating activities" subsumes a variety of possibilities, including casual labour (kibarua). Barker (1989) discussed kibarua and said that it "refers to day labour or piece of work paid either in cash or in goods such as sugar or salt," beer brewing and sale, charcoal burning and sale, craftwork, such as the making of sisal ropes, and the making of decorated calabashes (used for milk) from guards. However, it should be noted that the degree to which households depend upon causal labour for income generation was inversely correlated with elevation. Thus, the average amount of money that people earned and the degree to which they depended upon casual labour for economic survival was greater in the valley than on the escarpment or in the highlands. 
Casual labour is not gender specific. It is regularly performed by both males and females alike. Other small-scale income-generating activities tend to be more gender specific. For example, the burning and sale of charcoal is something which is undertaken primarily by males, and more in the valley (due to the greater availability of trees) than elsewhere. In theory, a person has to possess a license in order to burn trees to make charcoal; in reality, few people actually do. As it leaves the valley, the price steadily increases.

Although officially proscribed, the brewing and sale of traditional beer (busaa), made with fried, fermented maize (maiyek), and millet (bitek) meal, is very common in all three ecological zones of Keiyo. Moreover, it can be a substantial source of income, especially for women. As mentioned earlier, in the past, this beer is often used to compensate the members of a communal work party and today, the workers who come to perform labour during critical periods in the agricultural cycle are still rewarded with busaa (Chang'ach, 2011b). Busaa is also freely consumed on many other occasions, including, but not restricted to, ceremonial events, such as weddings, circumcisions, and naming of infants. However, presently, busaa has become a commodity and as such it is also brewed specifically with the intent of making money. An addition to busaa is the refining of a spirit known as chang 'aa. When it is available, people show up to drink and socialize with others in the area. Accordingly, this income-generating strategy seems to be most common among female-headed households and it is practiced in all the three ecological zones (Chang'ach, 2011b).

Craftwork is limited in Keiyo. Making ropes from sisal fibres and calabashes from guards is about the only craft activity that was carried out in the three ecological zones and is a minor supplementary source of income. This activity is mostly done by women.

The information gathered in this study supports the assertion that life is fundamentally different in the highlands. Additionally, it is maintained that this divergence is rooted in the much more favourable economic opportunity structure in the highlands than on the escarpment or in the valley. The cause of the superior opportunity structure in the highlands is lodged equally in ecological and historical factors.

\section{Conclusion}

This paper first discussed the efforts and actions by the Keiyo to address the challenges of agrarian change and rural transformation in Kenya. The paper explains that these strategies further widen the scope of engagement in the economy by Keiyo households.

The discussion of households in Keiyo, considered their size and composition, as well as the distribution of household resources across the three ecological zones under consideration. To review this discussion, it was found that, in terms of land and livestock holdings, water sources and distance to them, and housing materials and construction, the highlands ecological zone is definitely the most favourable one, with the valley the least and the escarpment intermediate. While there were certainly affluent, prosperous households on the escarpment and in the valley, they were much fewer in number than in the highlands. It is suggested that, as a reflection of the more favourable economic opportunity structure there, the distribution of resources was more equitable among households in the highlands than either of the other two areas.

The different economic opportunity structures of these three areas were reflected in the make-up of households. On average, households were largest in the highlands, smallest in the valley, and intermediate on the escarpment. This was due to the fact that the population of the highlands was younger and that there were more children there than in the other two areas. 
This paper has also examined the economic strategies that people from the three ecological zones in Keiyo used and the activities in which they engaged to make a living. The study has endeavoured to show that people felt most secure in the highlands and that they were better able to meet their own economic expectations there than elsewhere. It has also been suggested that the economic strategies of people in these three ecological zones led them to deliberately seek to diversify their economic activities both in order to reduce risk/uncertainty and also in the attempt to turn a profit. In this regard, those households that were able to combine on-farm activities with off-farm sources of income were generally the most successful and secure. However, the ability to diversify was not equally distributed. It was dependent upon access to capital and as such it tends to be the greatest in the highlands. Nevertheless, the economic opportunity structure of the highlands was so benevolent that people there could succeed without extensively diversifying, whereas for households on the escarpment and in the valley, diversification was a prerequisite for economic success.

Households from those three ecological zones engaged in a wide variety of economic activities: farming, animal husbandry, casual labour, beer brewing and sale, charcoal burning and sale, wage labour/salaried employment, and entrepreneurial/business endeavours. Generally, the amount of money that could be earned from any one or more of these categories was greatest in the highlands, intermediate on the escarpment, and least in the valley. Total income from all sources combined clearly correlated directly with elevation.

It is demonstrated from this paper that the perceived economic security and ability to meet one's own economic expectations were also greatest in the highlands. These differences were not the result of varying attitudes towards the desirability of "development." The better life that people enjoyed in the highlands (symbolized in things like house construction and fenced farm plots) was and is aspired to by nearly all people today. However, with the exception of a few well-to-do individuals in the valley and on the escarpment, this standard of living was generally available only to those fortunate enough to be endowed with the right mix of resources: the residents of the highlands.

\section{References}

Acland, J. O. (1986). East African crops. Essex, U.K.: Longman Group.

Barker, J. (1989). Rural communities under stress peasant farmers and the state in Africa. New York, N.Y.: Cambridge University Press.

Chang'ach, J. K. (2011a). Agro-pastoralism in Kenya. Verlag: LAP LAMBERT Academic Publishing GmbH \& Co. KG, Deutschland.

Chang'ach, J. K. (2011b). Economic opportunities and differentiation in Kenya. Verlag: LAP LAMBERT Academic Publishing $\mathrm{GmbH} \& \mathrm{Co} . \mathrm{KG}$, Deutschland.

Chebet, S., \& Dietz, T. (2000). Climbing the cliff: A history of the Keiyo. Eldoret: Moi University Press.

Halperin, R. (1992). The livelihood of kin: Making ends meet the Kentucky way. Austin: University of Texas Press.

Harden, B. (1990). Africa: Dispatches from a fragile continent. Boston, M.A.: Houghton Mifflin.

Huntingford, G. W. B. (1963). The people of the interior of East Africa by its modern inhabitants. In R. Oliver, \& G. Mathews (Eds.), History of East Africa (Vol. 1). Oxford, U.K.: Oxford Clarendon Press.

Karp, I. (1978). Fields of change among the Iteso. London, U.K.: Routledge and Kegan Paul.

Kipkorir, B. E. (1973). The Marakwet of Kenya: A preliminary study. Nairobi: Kenya Literature Bureau.

Kipkorir, B. E., \& Ssenyonga, J. W. (1985). Socio-cultural profile of Elgeyo-Marakwet district. Nairobi: Institute of African Studies, University of Nairobi.

Leys, C. (1975). Under development in Kenya: The political economy of neo-colonialism 1964-1971. London, U.K.: Heinemann.

Little, P. D. (1985). Social differentiation and pastoralist sedentarization in Northern Kenya. Journal of the International African Institute, 55(3), 243-261.

Massam, J. A. (1968). The cliff dwellers of Kenya. London, U.K.: Frank Cass and Company. 
Maxon, R. M. (2003). Going their separate ways: Agrarian transformation in Kenya, 1930-1950. London, U.K.: Associated University Press.

Ortiz, S. (1973). Uncertainties in peasant farming. London, U.K.: Athlone Press.

Republic of Kenya. (1985). District Atlas Elgeyo Marakwet, Iten, Kenya. Nairobi: Government Printer.

Republic of Kenya. (1991a). Development and employment in Kenya: A strategy for the transformation of the economy (A report of the Presidential Committee on employment). Nairobi: Government Printer.

Republic of Kenya. (1991b). National poverty eradication plan, 1999-2015. Nairobi: Government Printer.

Republic of Kenya. (1991c). Development and employment in Kenya: A strategy for the transformation of the economy (A report of the Presidential Committee on employment). Nairobi: Government Printer.

Republic of Kenya. (1994). Keiyo district development plan 1994-1996. Nairobi: Government Printer.

Republic of Kenya. (1997). Keiyo district development plan 1997-2001. Nairobi: Government Printer.

Republic of Kenya. (1999). National poverty eradication plan, 1999-2015. Nairobi: Government Printer.

Schneider, H. K. (1979). Livestock and equality in East Africa: The economic basis for social structure. Bloomington: Indiana University Press.

Schneider, H. K. (1981). The Africans: An ethnological account. New York, N.Y.: Prentice Hall. 